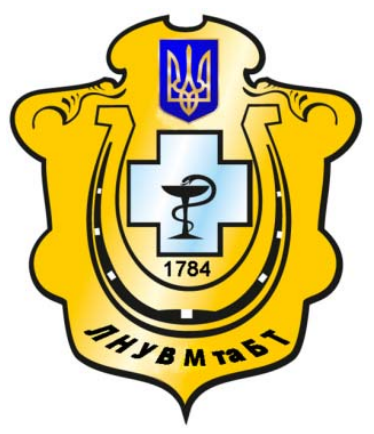

Науковий вісник Львівського національного університету ветеринарної медицини та біотехнологій імені С.3. Гжицького

Scientific Messenger of Lviv National University of Veterinary Medicine and Biotechnologies named after S.Z. Gzhytskyj

doi:10.15421/nvlvet7131

ISSN 2413-5550 print

ISSN 2518-1327 online

$\underline{\text { http://nvlvet.com.ua/ }}$

УДК 619:615.637.65

\title{
Вплив ферровету 7,5 \% і фероселу Т на концентрацію мінеральних речовин в сироватці крові поросят, хворих на ферумдефіцитну анемію
}

\author{
В.Б. Тодорюк, Б.В. Гутий, Р.І. Хомик, Р.О. Васів \\ applleman@gmail.com
}

\begin{abstract}
Львівський національний університет ветеринарної медицини та біотехнологій імені С.3. Гжицького, вул. Пекарська, 50, м. Львів, 79010, Україна
\end{abstract}

\begin{abstract}
У статті представлено результати експериментальних досліджень з вивчення фармакологічної дї ферумодекстранових препаратів - ферровету-7,5\%, який в 1 мл декстрану містить 75 мг тривалентного Феруму, та фероселу-T, в 1 мл якого, окрім 75 мг тривалентного Феруму, додатково міститься 0,3 мг Селену (у формі натрію селеніту) на концентрацію мінеральних речовин в сироватиі крові поросят за латентної ферумодефіцитної анемії.

Встановлено, щзо на 21 добу постнатального періоду, у сироватиі крові поросят за латентної ферумодефіцитної анемії, рівень Кальиію був на 11,8\%, а Фосфору - на 8,4\% нижчим. Запаси Феруму у вказаний період з органів-депо були повністю використані для гемопоезу, а надходження його з молоком матері недостатнє для оптимального еритроцитопоезу, тому конщентрація Феруму в сироватці крові поросят не задовольняла його потребу для гемопоезу.

У разі застосування ферумодекстранових препаратів для лікування хворих на ферумодефіичитну анемію поросят встановлено збільшення Кальцію, Фосфору, Селену та Феруму. Так на 21 добу після народження у поросят, яким вводили ферровет 7,5\%, у сироватиі крові концентрачія Кальцію збільшилася на 30,0\% (p<0,01), Фосфору - на 15,6\%, а яким вводили феросел $T$ відповідно збільшилася на 33,4\% $(p<0,01)$ і 19,3\%. Кониентрачія Селену та Феруму у сироватиі крові поросят дослідних груп, яким застосовували ферровет 7,5\% та феросел $T$, вірогідно збільшувалася вже починаючи з 7 доби досліду.

Показано, щзо за ферумодефіиитної анемії поросят ефективність застосування препарату феросел-T з лікувальною та профілактичною метою є вищою, ніж препарату ферровет-7,5\%, що зумовлено сукупною дією Феруму і Селену.

Ключові слова: Ферум, Селен, Ферровет-7,5\%, Феросел-T, анемія ферумодефіцитна.
\end{abstract}

\section{Влияние ферровета 7,5\% и феросела Т на концентрацию минеральных веществ в сыворотке крови поросят, больных ферумдефицитной анемией}

\author{
В.Б. Тодорюк, Б.В. Гутый, Р.И. Хомик, Р.А. Васив \\ applleman@gmail.com
}

\begin{abstract}
Львовский национальный университет ветеринарной медицины и биотехнологий имени С.3. Гжицкого, ул. Пекарская, 50, г. Львов, 79010, Украина
\end{abstract}

В статье представлены результаты экспериментальных исследований по изучению фармакологического действия ферумодекстранових препаратов - ферровета-7,5\%, который в 1 мл декстрана содержит 75 мг трехвалентного железа, $u$ феросела-T, в 1 мл которого, кроме 75 мг трехвалентного железа, дополнительно содержится 03 мг Селена (в форме натрия селенита) на конщентрачию минеральных веществ в сыворотке крови поросят за латентной ферумодефицитной анемии.

Установлено, что на 21 сутки постнатального периода, в сыворотке крови поросят за латентной ферумодефицитной анелии, уровень кальция был на 11,8\%, а фосфора - на 8,4\% ниже. Запасы железа в указанный период из органов-депо были полностью использованы для гемопоэза, а поступления его с молоком матери недостаточно для оптимального ерит-

\section{Citation:}

Todoriuk, V.B., Gutyj, B.V., Khomyk, R.I., Vasiv, R.O. (2016). Influence of ferrovet 7.5\% and ferosel T on the concentration of mineral substances in the blood serum of piglets suffering from Iron deficit anemia. Scientific Messenger LNUVMBT named after S.Z. Gzhytskyj, 18, 3(71), 139-143. 
роцитопоеза, поэтому концентрация железа в сыворотке крови поросят не удовлетворяла его потребности для гемопоэза.

В случае применения ферумодекстранових препаратов для лечения больных ферумодефицитную анемию поросят установлено увеличение кальция, фосфора, селена и железа. Так на 21 сутки после рождения у поросят, которьм вводили ферровет 7,5\%, в сыворотке крови концентрация кальция увеличилась на 30,0\% (p < 0,01), фосфора - на 15,6\%, а которьм вводили феросел-Т соответственно увеличилась на 33,4\% (p < 0,01) и 19,3\%. Концентрация Селена и железа в сыворотке крови поросят опытных групп, которым применяли ферровет 7,5\% и феросел Т, вероятно увеличивалась уже начиная с 7 суток опыта.

Показано, что при ферумодефицитной анемии поросят эффективность применения препарата феросел-Т с лечебной и профилактической целью выше, чем препарата ферровет-7,5\%, что обусловлено совокупным действием железа и селена.

Ключевые слова: Железо, Селен, Ферровет-7,5\%, Феросел-Т, анемия ферумодефицитная.

\title{
Influence of ferrovet $7.5 \%$ and ferosel $T$ on the concentration of mineral substances in the blood serum of piglets suffering from Iron deficit anemia
}

\author{
V.B. Todoriuk, B.V. Gutyj, R.I. Khomyk, R.O. Vasiv \\ applleman@gmail.com
}

In the article presents the results of experimental studies on the pharmacological action of iron dextran preparationsferrovet-7.5\%, which in $1 \mathrm{ml}$ dextran containing $75 \mathrm{mg}$ of ferric iron, and ferosel-T, $1 \mathrm{ml}$ of which, in addition to $75 \mathrm{mg}$ of ferric iron, additionally contains $0.3 \mathrm{mg}$ selenium (in the form of sodium selenite) the concentration of minerals in the blood serum of pigs for latent iron deficit anemia.

Established that at 21 days postnatal period, in the whey of blood of piglings for latent iron deficit anemia, a level of Calcium was on $11.8 \%$, and to Phosphorus - on to $8.4 \%$ lower. Reserves of iron in the indicated period of depot were fully used for hematopoietic and receipt of its mother's milk insufficient for optimal erytrotsytopoez because the concentration of iron in the blood serum of pigs did not satisfy his need for hematopoiesis.

In the case of iron dextran preparations for the treatment of iron deficiency anemia pigs found an increase in Calcium, Phosphorus, Selenium and Iron. So on 21 days after birth for piglings, which entered ferrovet 7.5\%, in the whey of blood the concentration of Calcium was increased on 30.0\% ( $r<0.01)$, to Phosphorus - on 15.6\%, and which ferosel-T was entered accordingly increased on $33.4 \%(r<0.01)$ and $19.3 \%$.

The concentration of Selenium and Iron in the blood serum of piglets research groups, which used ferrovet $7.5 \%$ and ferosel-T is likely to have increased since 7 day experiment.

Shown that iron deficit anemia of piglings efficiency of application of preparation of ferosel-T with a medical and prophylactic purpose is higher, than to preparation of ferrovet-7.5\%, that predefined by the combined action of Iron and Selenium.

Key words: Iron, Selenium, Ferrovet-7.5\%, Ferosel-T, Iron deficit anemia.

\section{Вступ}

Аліментарна ферумдефіцитна анемія поросят розвивається внаслідок недостатнього запасу Феруму в їхньому організмі після народження і високими потребами в ньому в перші 2 місяці постнатального періоду. Внаслідок інтенсивного росту поросят анемія розвивається швидко і важко протікає (Karelin, 1983; Samohin, 1999; Vorobev, 2001).

За повідомленнями в літературі, при інтенсивному веденні свинарства на промисловій основі, за відсутності своєчасних профілактичних заходів, захворювання новонароджених поросят на ферумдефіцитну анемію складає $100 \%$, а загибель досягає до $35 \%$ (Scherbakov and Korobov, 2002; Todoriuk, 2012).

Нормальну життєдіяльність організму тварин забезпечує велика група біологічно активних речовин, в тому числі макро- і мікроелементи. Вони беруть участь в регуляції важливих біологічних процесів на клітинному рівні.

Кальцій і Фосфор є основними компонентами кісткової тканини, тому від їх рівня в організмі залежить ріст і розвиток поросят в постнатальний період. Поряд з цим іонізований Кальцій забезпечує функціональний стан нервової системи, а Фосфор бере участь у фосфорилюванні при окисно-відновних процесах (Kalnitskiy, 1985).
Мікроелемент Ферум - це основний компонент для синтезу гемоглобіну в процесах гемопоезу. Від маси і концентрації гемоглобіну в еритроциті залежить транспорт Оксигену до тканин, а від цього інтенсивність метаболічних процесів у клітинах (Troshin et al., 2007).

Селен як мікроелемент володіє високою біологічною активністю. Він бере участь в метаболічних процесах у м'язовій тканині, зокрема в тканинному диханні міофібрил. За низького рівня Селену в організмі ягнята i телята хворіють на білом'язову хворобу (Belajev et al., 2007).

\section{Матеріал і методи досліджень}

Досліди проведено у ФГ «Агро-Мік», що розташоване в селі Ошихліби Кіцманського району Чернівецької області. Метою проведених досліджень було - в дослідах на поросятах-сисунах, спонтанно хворих на латентну аліментарну ферумодефіцитну анемію, в порівняльному аспекті, дослідити вплив ферумодекстранових препаратів ферровету-7,5 та фероселу-Т на функціональний стан печінки. Поросят розділили на 3 групи-аналоги по 10 голів у кожній. Поросятам першої групи (К), що слугували контролем, за латентної ферумодефіцитної анемії ферумодекстранові препарати не вводили. У тварин контрольної групи, за динамікою змін біохімічних показ- 
ників крові впродовж тридцяти діб постнатального періоду вивчали розвиток ферумодефіцитної анемії. Для профілактики ферумодефіцитної анемії поросятам першої дослідної групи (Д1) застосовували ферровет-7,5\%, який в 1 мл декстрану містить 75 мг Феруму, а другої (Д2) - феросел-Т, який в 1 мл декстрану, окрім 75 мг тривалентного Феруму, додатково містить 0,3 мг Селену у формі натрію селеніту. Обидва препарати вводили тваринам внутрішньом'язово на 3-ю й 10-у добу після народження в дозі 1 мл.

\section{Результати та їх обговорення}

У процесі проведених нами досліджень (табл. 1) встановлено, що на 3 добу після народження у сироватці крові поросят, хворих на ферумдефіцитну анемію, концентрація Кальцію складала

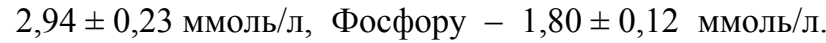
Така концентрація мікроелементів знаходиться в межах фізіологічних величин для поросят великої білої породи (Troshin et al., 2007). Співвідношення між Кальцієм і Фосфором у сироватці крові тварин $(1: 0,45)$ також являється оптимальним.

Встановлено, що на 7 і 14 доби постнатального періоду концентрація Кальцію у сироватці крові поросят була нижчою на 2,7 і 3,2\% порівняно 33 добою після народження (табл. 1).

Отже, в перші 2 тижні після народження, в організмі поросят концентрація Кальцію і Фосфору достатня для росту та розвитку, в тому числі для формування скелету.

На 21 добу постнатального періоду, у сироватці крові поросят контрольної групи, рівень Кальцію був на 11,8\%, а Фосфору - на 8,4\% нижчим, порівняно 33 добою. На такому ж рівні вміст досліджуваних макроелементів залишався і на 30 добу після народження. Вважаємо, що зниження рівня Кальцію і Фосфору в сироватці крові на 3 тиждень постнатального періоду зумовлене активним формуванням кісткової тканини і високою потребою організму поросят в макроелеменTax.

При дослідженні концентрації мікроелементів у сироватці крові поросят хворих на ферумдефіцитну анемію, встановлено, що на 3 добу після народження концентрація Феруму і Селену була на межі мінімальної фізіологічної потреби і складала: Феруму $18,32 \pm 0,26$ мкг/л, Селену - 1,40 \pm 0,06 мкг/л.

3 другого тижня постнатального періоду концентрація Феруму в сироватці крові поросят прогресивно знижувалася: на 7 добу - на 7,0\%, на 14 добу - на 20,2\%, на 21 добу - 37,1\%, у порівнянні з 3 добою після народження, і залишалася на такому ж низькому рівні на 30 добу постнатального періоду.

Концентрація Селену в сироватці крові хворих поросят 33 до 30 доби постнатального періоду поступово знижувалася і відповідно коливалася у межах 1,40 - 1,22 мкмоль/л.

Вважаємо, що в перші 2 тижні після народження в організмі поросят наявні запаси Феруму в органахдепо, тому його рівень в сироватці крові знижувався поступово, у міру використання у процесах еритроцитопоезу.
На 21 добу постнатального періоду запаси Феруму 3 органів-депо були повністю використані для гемопоезу, а надходження його з молоком матері недостатнє для оптимального еритроцитопоезу, тому концентрація Феруму в сироватці крові поросят не задовольняла його потребу для гемопоезу. Адже поросяті в підсисний період для росту та еритроцитопоезу щоденно потрібно 50 мг Феруму, а 3 молоком матері воно отримує лише 10 мг, задовольняючи його потребу лише на 10 - 12\% (Anders, 1997; Todoriuk, 2012).

При застосуванні поросятам, хворим на ферумдефіцитну анемію, ферровету 7,5\% і фероселу-Т в перші 2 тижні після народження концентрація Кальцію і Фосфору у сироватці крові була така ж, як у поросят контрольної групи, яким феродекстранові препарати не вводили.

На 21 добу після народження у поросят, яким вводили ферровет 7,5\%, у сироватці крові концентрація Кальцію збільшилася на 30,0\% (p < 0,01), Фосфору на 15,6\% відносно показників контрольної групи поросят і залишилась на такому високому рівні на 30 добу.

У поросят, яким вводили феросел-Т на 21 добу після народження, концентрація Кальцію підвищилася на $33,4 \%$ (p < 0,01), Фосфору - на $19,3 \%$, а на 30 добу відповідно Кальцію - на 38,0\% ( $<0,05)$, Фосфору на 14,0\% відносно величин контрольної групи поросят.

Вважаємо, що високий рівень Кальцію і Фосфору в сироватці крові поросят, яким вводили феродекстранові препарати, зумовлений всмоктуванням їх 3 кишечника для забезпечення високих середньодобових приростів живої маси та формування скелету.

Внаслідок інтенсивного росту і розвитку у поросят збільшується потреба в макроелементах, особливо в Кальцію і Фосфорі. Вони інтенсивно всмоктуються 3 кишечника, що підтверджується високим рівнем цих макроелементів у сироватці крові поросят.

Концентрація макроелементів у сироватці крові тварин регулюється білками ентероцитів (трансферинами) слизової оболонки кишечника. Чим більша потреба організму в Кальцію і Фосфорі, тим в більших кількостях вони всмоктуються 3 кишечника (Alekseev, 2004).

При дослідженні концентрації мікроелементів у сироватці крові поросят, яким для лікування при ферумдефіцитній анемії застосували феродекстранові препарати, встановлено збільшення рівня Феруму i Селену.

Після введення ферровету 7,5\% концентрація Феруму у сироватці крові поросят на 7 добу підвищилася на $15,9 \%$ (p < 0,001), а на 14 добу - на 42,7\% $(\mathrm{p}<0,001)$ відносно контрольної групи тварин і утримувалася на такому ж високому рівні на 21 і 30 доби постнатального періоду.

Аналогічно і майже в таких кількостях підвищувалася концентрація Феруму у сироватці крові поросят, яким вводили феросел-Т (табл. 1).

У поросят, яким вводили ферровет 7,5\%, концентрація Селену у сироватці крові на 30 добу постнатального періоду коливалася у межах $1,38 \pm 0,03$ мкмоль/л. 
Таблиияя 1

Концентрація мінеральних речовин в сироватці крові поросят, хворих на ферумдефіцитну анемію, яким вводили ферровет 7,5\% і феросел T $(\mathrm{M} \pm \mathbf{m} ; \mathbf{n}=10)$

\begin{tabular}{|c|c|c|c|c|c|c|}
\hline \multirow{2}{*}{ Показник } & \multirow{2}{*}{$\begin{array}{l}\text { Група } \\
\text { тварин }\end{array}$} & \multicolumn{5}{|c|}{ Доба дослідження крові } \\
\hline & & $3-\Re$ & $7-\mathrm{a}$ & $14-\mathrm{a}$ & $21-\mathrm{a}$ & $30-\mathrm{a}$ \\
\hline \multirow{3}{*}{$\begin{array}{l}\text { Кальцій } \\
\text { ммоль/л }\end{array}$} & $\mathrm{K}$ & $2,94 \pm 0,23$ & $2,86 \pm 0,14$ & $2,85 \pm 0,24$ & $2,63 \pm 0,25$ & $2,64 \pm 0,36$ \\
\hline & Д $_{1}$ & $2,86 \pm 0,34$ & $2,78 \pm 0,12$ & $3,14 \pm 0,15$ & $3,42 \pm 0,17 * *$ & $3,32 \pm 0,24$ \\
\hline & Д $_{2}$ & $2,92 \pm 0,26$ & $2,98 \pm 0,15$ & $3,21 \pm 0,12$ & $3,51 \pm 0,24 * *$ & $3,64 \pm 0,25^{*}$ \\
\hline \multirow{3}{*}{$\begin{array}{l}\text { Фосфор } \\
\text { ммоль/л }\end{array}$} & $\mathrm{K}$ & $1,80 \pm 0,12$ & $1,85 \pm 0,16$ & $1,84 \pm 0,15$ & $1,66 \pm 0,18$ & $1,69 \pm 0,16$ \\
\hline & Д $_{1}$ & $1,86 \pm 0,15$ & $1,92 \pm 0,14$ & $1,98 \pm 0,18$ & $1,92 \pm 0,15$ & $1,96 \pm 0,14$ \\
\hline & Д $_{2}$ & $1,82 \pm 0,14$ & $1,96 \pm 0,12$ & $1,96 \pm 0,14$ & $1,98 \pm 0,16$ & $1,93 \pm 0,18$ \\
\hline \multirow{3}{*}{$\begin{array}{l}\text { Ферум } \\
\text { мкмоль/л }\end{array}$} & $\mathrm{K}$ & $18,32 \pm 0,26$ & $17,12 \pm 0,14$ & $15,24 \pm 0,15$ & $13,36 \pm 0,14$ & $13,23 \pm 0,14$ \\
\hline & Д $_{1}$ & $18,34 \pm 0,15$ & $\begin{array}{c}19,84 \pm 0,16 \\
* * *\end{array}$ & $\begin{array}{c}21,75 \pm 0,16 \\
* * *\end{array}$ & $\begin{array}{c}21,47 \pm 0,12 \\
* * *\end{array}$ & $\begin{array}{c}21,82 \pm 0,15 \\
* * *\end{array}$ \\
\hline & Д $_{2}$ & $18,46 \pm 0,18$ & $\begin{array}{c}19,86 \pm 0,14 \\
* * *\end{array}$ & $\begin{array}{c}21,84 \pm 0,14 \\
* * *\end{array}$ & $\begin{array}{c}22,02 \pm 0,18 \\
* * *\end{array}$ & $\begin{array}{c}22,14 \pm 0,16 \\
* * *\end{array}$ \\
\hline \multirow{3}{*}{$\begin{array}{l}\text { Селен } \\
\text { мкмоль/л }\end{array}$} & $\mathrm{K}$ & $1,40 \pm 0,06$ & $1,33 \pm 0,03$ & $1,26 \pm 0,02$ & $1,22 \pm 0,03$ & $1,24 \pm 0,03$ \\
\hline & Д $_{1}$ & $1,48 \pm 0,03$ & $1,38 \pm 0,02$ & $1,39 \pm 0,03 * *$ & $\begin{array}{c}1,39 \pm 0,02 \\
* * *\end{array}$ & $\begin{array}{c}1,38 \pm 0,03 \\
* *\end{array}$ \\
\hline & Д $_{2}$ & $1,46 \pm 0,08$ & $\begin{array}{c}1,68 \pm 0,03 \\
* * *\end{array}$ & $\begin{array}{c}1,72 \pm 0,08 \\
* * *\end{array}$ & $\begin{array}{c}1,70 \pm 0,06 \\
* * *\end{array}$ & $\begin{array}{c}1,68 \pm 0,02 \\
* * *\end{array}$ \\
\hline
\end{tabular}

Примітка: ступінь вірогідності ${ }^{*}-\mathrm{p}<0,05 ; *_{-}{ }_{-}<0,01 ; * * *_{-}-\mathrm{p}<0,001$.

Після введення поросятам фероселу Т концентрація Селену у сироватці крові на 7 добу підвищилася на $26 \%(\mathrm{p}<0,001)$, на 14 добу - на $37 \%(\mathrm{p}<0,001)$ відносно показників крові, взятої від контрольної групи поросят, і залишалася на такому ж високому рівні на 21 і 30 доби постнатального періоду.

Підвищення концентрації Феруму і Селену в сироватці крові поросят дослідних груп зумовлено резорбцією їх із місця ін'єкції досліджуваних препаратів. Стабільний рівень досліджуваних мікроелементів упродовж 30 діб зумовлений поступовим всмоктуванням їх після внутрішньом'язового введення.

\section{Висновки}

1. На 3 добу після народження i протягом підсисного періоду, у сироватці крові поросят достатня кількість Кальцію і Фосфору, необхідних для забезпечення фізіологічних процесів функціонування організму;

2. Концентрація Феруму і Селену в сироватці крові новонароджених поросят знаходиться на межі мінімальних фізіологічних показників. Запаси вказаних мікроелементів вичерпуються за 14 діб постнатального періоду росту і розвитку, після чого в поросят розвивається ферумдефіцитна анемія;

3. Після внутрішньом'язового уведення ферровету 7,5 \% і фероселу-Т концентрація Кальцію, Фосфору, Феруму та Селену в сироватці крові поросят відновлюється до нормативних значень.

\section{Бібліографічні посилання}

Samohin, V.T. (1999). Profilaktika narusheniy obmena mikroelementov u zhivotnyih [Disturb of

micronutrient metabolism in animals]. M., Kolos (in Russian).
Karelin, A.I. (1983). Anemiya porosyat [Piglets anemiya]. M., Rosselhozizdat (in Russian).

Scherbakov, H.H., Korobov, A.B. (2002). Vnutrennie bolezny zyvotnuch [Domestic animal diseases]. SPb., Publ. Lanj (in Russian).

Vorobev, P.A. (2001). Anemicheskiy sindrom v klinicheskoy praktike [Anemic syndrome in clinical practice]. M., Nyudiamed (in Russian).

Kalnitskiy, B.D. (1985). Mineralnyie veschestva v kormlenii zhivotnyih [Minerals in animal nutrition]. L., Agropromizdat. (in Russian).

Belajev, B.I., Chabunin, S.B., Balim, U.P. (2007). Vliyanie preparatov selena na produktivnost i reproduktivnyie funktsii svinomatok [Effect of selenium on the productivity of sows and reproductive functions]. Nautsno proisvodstvenij journal Research and Production Journal. 2, 38-41 (in Russian).

Guseinov, T.M. (1990). Utsastie selenu w regulacii peroxydnego ocislenia lipidov biomembran i activnost glutamatperoxydase [Participation of selenium in the regulation of lipid peroxidation and activity of biomembranes glyutamat-peroxidation]. Biochemie -Biochemistry. 55(3), 499-507 (in Ukrainian).

Troshin, A.N., Nechaeva, A.B., Kogdenko, N.V. (2007). Preparatyi zheleza $\mathrm{V}$ meditsine i veterinarii vchera, segodnya i zavtra [Iron supplementation in human and veterinary medicine yesterday, today and tomorrow]. Nachnyiy zhurnal KubGAU — Research Journal KubGAU. 28(4), 45-53 (in Russian).

Todoriuk, V.B. (2012). Vplyw preparatu Minbivitu na profilacticu anernii porosat [Influence of Minbevit on the prevention of anemia of piglets]. Nauc. Visnic LNUVMBT - Research Bulletin LNUVMIBT, 14, 3(53), 273-278 (in Ukrainian).

Bulah, A.A., Kozlovskiy, A.Yu., Fedorova, M.A. i dr. (2011). Biologicheskaya rol selena V organizme 
zhivotnyih [Biological role of selenium in animals]. Povyishenie intensivnosti i konkurentosposobnosti otrasley zhivotnovodstva : tezisyi dokladov Mezhdunarodnoy nauchnoprakticheskoy konferentsii (14-15 sentyabrya 2011 g.). Zhodino. 2, 17-19 (in Russian).

Kozniewicz, D., Dobgansci, Z., Kovacz, B., Formiewicz, D. (2003). Bioaval ability of zinc, selenium and chromium from yeast saccharomices cerevisial for swine. 4, 171-182.
Levchenko, V.I., Novozhitska Yu. M., Sahnyuk V.V. ta in. (2004). Biohimichni metodu doslidzhennya krovi tvarin: metodichnI rekomendatsii [Biochemical methods of animal blood: guidelines]. K. (in Ukrainian).

Anders, N.C. (1997). Iron deficiency lessons from anemie mice. Biol. Med. 70, 219-226.

Alekseev, H.A. (2004). Anemii [Anemia]. SPb., Hyppokrat (in Russian).

Стаття надійшла до редакичї 1.10.2016 